\title{
IMPLEMENTASI PERATURAN DAERAH KABUPATEN BADUNG NOMOR 7 TAHUN 2012 TENTANG PENGATURAN PASAR TRADISIONAL DI KABUPATEN BADUNG
}

\author{
I Putu Gede Murditayasa, I Nyoman Putu Budiartha, Desak Gde Dwi Arini \\ Fakultas Hukum Universitas Warmadewa, Denpasar-Bali, Indonesia
}

\begin{abstract}
Abstrak
Pasar tradisional merupakan tempat bertemunya pedagang dan pembeli, dimna perdagangan dilakukan dengan negosiasi dan tawar menawar. Namun, seiring perkembangan zaman terjadi penurunan kinerja pasar tradisional karena adanya pasar modern, dan lemahnya daya saing para pegusaha yang melakukan kegiatan dalam pasar tradisional. Penelitian ini bertujuan untuk menjelaskan tata cara implementasi revitalisasi Peraturan Daerah Kabupaten Badung Nomor 7 Tahun 2012 tentang pengaturan pasar tradisional di Kabupaten Badung dan menganalisis faktor penghambat implementasi Peraturan Daerah tersebut. Penelitian ini menggunakan tipe penelitian hukum empiris dengan menggunakan pendekatan perundang-undangan. Data yang digunakan adalah data primer dan sekunder. Hasil penelitian menunjukkan bahwa Implementasi revitalisasi pembangunan pasar tradisional di Daerah badung ialah salah satu gebrakan dari pemerintah yang bertugas di daerah dalam hal menghidupkan serta mengembangkan kembali pasar yang sebelumnya mengalami penurunan akibat dari persaingan dengan pasar modern yang tumbuh, untuk itu dengan diundangkannya peraturan daerah nomor 7 Tahun 2012 tentang penataan dan pembinaan pasar tradisional, pusat perbelanjaan dan toko modern menjadikan eksistensi pasar tradisional menjadi lebih baik dan perkembangannya, yang kedua Hambatan implementasi peraturan daerah nomor 7 Tahun 2012 tentang penataan dan pembinaan pasar tradisional, pusat perbelanjaan dan toko modern terletak pada faktor penegakan aturan, faktor dana, faktor pengelolaan dan faktor masyarakat.
\end{abstract}

Kata Kunci: Implementasi; Peraturan Daerah; Pasar Tradisional

\begin{abstract}
Traditional markets are a meeting place for traders and buyers, where trade is carried out by negotiation and bargaining. However, along with the times there has been a decline in the performance of traditional markets due to the existence of modern markets and the weak competitiveness of entrepreneurs conducting activities in traditional markets. This study aims to explain the procedures for implementing the revitalization of the Regional Regulation of Badung Regency Number 7 of 2012 concerning the regulation of traditional markets in Badung Regency and to analyze the inhibiting factors for the implementation of the Regional Regulation. This study uses an empirical legal research type using a statutory approach. The data used are primary and secondary data. The results show that the implementation of the revitalization of traditional market development in the Badung area is one of the moves by the government in charge of the regions in terms of reviving and re-developing markets which previously experienced a decline due to competition with growing modern markets, for this reason, the promulgation of regional regulation number 72012 concerning the arrangement and fostering of traditional markets, shopping centers and modern shops to make the existence of traditional markets better and their development, the second obstacle to the implementation of regional regulation number 7 of 2012 concerning the arrangement and development of traditional markets, shopping centers and modern shops lies in the enforcement factor, regulations, funding factors, management factors and community factors.
\end{abstract}

Keywords: Implementation; Local regulation; Traditional market

\section{PENDAHULUAN}

Pertumbuhan ekonomi di Kabupaten Badung 5 (Lima) tahun belakangan ini menunjukkan adanya laju yang selalu lebih tinggi dari pertumbuhan ekonomi kabupaten/Kota di seluruh Provinsi Bali bahkan seluruh Indonesia. Perkembangan ekonomi di Kabupaten Badung tentunya juga memiliki dampak yang sangat signifikan pada setiap aspek di daerah tersebut, selain mengalami perkembangan ekonomi yang sangat bagus juga parameter perkembangannya sangat pesat serta penyebarannya pun juga relatif dilakukan pemerataan di seluruh wilayah Pemerintahan Kabupaten Badung. 
Wilayah Badung, Kecamatan Kuta Selatan adalah salah satu daerah yang dijadikan tujuan pariwisata sehingga mengalami perkembangan yang sangat signifikan dalam bidang ekonomi yang mana di dalam perkembangannya tersebut pada berbagai macam tempat dan pusat perbelanjaanpun sebagai bagian dari transaksi ekonomi modern tumbuh di setiap sudut daerah. Berkembangnya segala macam bentuk industri toko modern di Kecamatan Kuta Selatan tentu berpengaruh pada masyarakat itu sendiri, hal ini di karenakan oleh dampak dari perkembangan ekonomi tentu saja ada psoitif dan negatifnya. Perkembangan dunia usaha di Indonesia belakangan ini semakin lama semakin meningkat, sehingga semakin menimbulkan dampak persaingan di berbagai sektor usaha. Salah satunya persaingan antara pasar tradisional dan pasar modern, hadirnya pasar modren akan menjadi tantangan bagi pasar-pasar tradisional (Kuriaty, 2017). Dampak positifnya tentu saja mempermudah kegiatan transaksi ekonomi yang ada di kehidupan masyarakat Kuta Selatan, akan tetapi dampak negatifnya ialah sudah terjadinya persaingan yang ketat di antara tempat perekonomian modern dengan temat perekonomian tradisional (Suartha.N, 2018).

Ditetapkannya Peraturan Daerah Kabupaten Badung Nomor 7 Tahun 2012 tentang Penataan dan Pembinaan Pasar Tradisional, Pusat Perbelanjaan serta Toko Modern membuat melonjaknya konsekuensi perubahan di bidang penataan perekonomian di wilayah Pemerintahan Kabupaten Badung, dimana terdapat juga aturan yang jelas untuk diberlakukan setiap masyarakat yang ingin berusaha dan ingin membuat tempat usaha di Kabupaten Badung. Peraturan bertujuan untuk menggairahkan dan meningkatkan perekoniman masyarakat setempat serta juga memudahkan transaksi perekonomian masyarakat di wilayah pedesaan itu sendiri.

Pasar tradisional saat ini sering dikalahkan dengan tempat ataupun pusat perbelanjaan yang lebih modern, dikarenakan kebersihan dan kenyamanan tempat, harga dan dagangan serta pelayanannya yang cenderung lebih baik dibandingkan dengan pasar tradisional yang terkesan kumuh dan kotor, sehingga hal ini menyebabkan omset atau pemasukan masyarakat yang berjualan di pasar tradisional seringkali lebih sedikit dibandingkan dengan tempat usaha di pertokoan ataupun pusat perbelanjaan seperti supermarket. Penurunan pasar tradisional lebih diakibatkan oleh faktor internal yang mengakibatkan kurangnya daya saing dibanding pasar modern. Lebih lanjut ditemukan, bahwa pasar tradisional yang berada dekat dengan supermarket terkena dampak yang lebih buruk dibanding yang berada jauh dari supermarket (Sarwoko, 2008).

Disisi lain pemerintah wajib untuk menata dan membina para pelaku usaha yang membuat tempat usaha atau tempat perbelanjaan modern agar sistem perekonomian di wilayah Kabupaten Badung dapat tetap bergairah dan terjaga dalam menjaga serta menunjang stabilitas perekonomian masyarakat. Dalam hal ini tentunya sangat diperlukan sinkornisisasi pengaturan tertulis antara pusat perbelanjaan modern dan juga pasar tradisional, pertokoan modern yang walaupun arah pasarnya sedikit berbeda, namun akan menimbulkan persaingan dalam mencukupi pendapatan yag maksimal masing-masing pada bentuk usahanya. Karena hal tersebutlah lalu implementasi masing-masing dari tempat, kasifikasi dan bentuk usaha tersebut sangatlah perlu untuk dilakukan pengkajian arah dan hasil yang akan didapat, untuk lalu bisa menciptakan timbulnya rasa keadilan di tengah-tengah kehidupan bermasyarakat yang mengharapkan persaingan usaha yang tentunya positif sehingga para pelaku usaha bisa meraih keuntungan dan dapat bersaing secara sehat.

Pemerintah Kabupaten Badung juga sudah menekankan terhadap cara pelayanan prima kepada seluruh aparatur pemerintahan agar tetap bisa membentuk kepercayaan pada masyarakat dari berbagai pelayanan publik yang dijalankan oleh orang-orang di pemerintahan itu sendiri maka dengan diterbitkan Peraturan Daerah Kabupaten Badung Nomor 7 Tahun 2012 tentang Penataan dan Pembinaan Pasar Tradisional, Pusat Perbelanjaan dan Toko Modern menyatakan dengan ini bahwa penataan serta pembinaan Pasar Tradisional, Pusat Perbelanjaan dan Toko Modern ialah kegiatan ataupun serangkaian kegiatan yang bertujuan untuk memberi dan mengupayakan secara totalitas kebutuhan masyarakat yang harus patuh atas dasar peraturan tertulis yang sudah diatur untuk orang-orang yang bertempat tinggal di Indonesia dan penduduk atas jasa, barang maupun pelayanan administrasi yang di fasilitasi pihak pemerintahan itu sendiri. Tujuan lain dari beberapa keputusan tersebut juga sebagai upaya dalam hal meningkatkan keteraturan perekonomian di Wilayah Pemerintahan Kabupaten Badung khususnya Kuta Selatan.

Berdasarkan beberapa hal yang telah di uraikan diatas tentu saja menunjukkan bahwa penataan dan pembinaan ialah hal perhatian penting untuk pemerintah Kabupaten Badung dalam suatu proses 
peningkatan keteraturan tempat usaha serta perijinan tempat usaha dalam tujuannya yakni menunjang perekonomian yang tentunya mengarah kepada perkembangan kegiatan perekonomian yang sehat di tengah-tengah masyarakat Kabupaten Badung ini.

Penelitian sebelumnya mengungkapkan bahwa implementasi kebijakan terkait dengan Toko Modern yang ditinjau dari model implementasi oleh Van Meter dan Van Horn khususnya jenis Minimarket CK di kecamatan Kuta Kabupaten Badung belum berjalan dengan optimal (Luh et al., 2018). Menurut Suantra et al., (2018) Penegakan hukum terhadap pelanggaran atas perizinan toko swalayan, secara normatif dilakukan dengan menjatuhkan sanksi administratif, sanksi pidana atau denda. Dalam praktik penegakan hukum dilakukan dengan memberikan peringatan lisan, peringatan tertulis, pembinaan, mengajukan izin dan pembekuan. Faktor yang menghamabat implementasi suatu peraturan aderah tentang pengaturan pasar tradisional adalah faktor pendorong seperti koordinasi, kondisi sosial dan kemajuan teknologi dan faktor penghambat seperti kepemimpinan, komunikasi dan kondisi lingkungan (Fajrul Umami, 2018). Sehubungan dengan hal tersebut Penelitian ini bertujuan untuk menjelaskan tata cara implementasi revitalisasi Peraturan Daerah Kabupaten Badung Nomor 7 Tahun 2012 tentang pengaturan pasar tradisional di Kabupaten Badung dan menganalisis faktor penghambat implementasi Peraturan Daerah.

\section{METODE PENELITIAN}

Peneliti dalam hal ini menggunakan tipe penelitian hukum empiris yang artinya peneliti mengumpulkan data-data hukum berupa implementasi peraturan daerah Kabupaten Badung nomor 7 Tahun 2012 tentang pengaturan pasar tradisional di Kabupaten Badung sebagai data primer dan didukung oleh data sekunder. Pendekatan yang digunakan dalam penelitian ini adalah pendekatan perundang-undangan atau disebut dalam bahasa asing The State Approach dengan cara menelaah peraturan perundang-undangan dan regulasi yang terkait dengan isu hukum dalam penelitian ini berupa meneliti aspek hukum yang ada serta pengaruh aturan hukum yang hidup di tengah-tengah masyarakat, dengan mengedepankan pendekatan yuridis dan sosiologis serta aspek ekonomis masyarakat.

\section{HASIL DAN PEMBAHASAN}

\section{Implementasi Revitalisasi Perda Kabupaten Badung Nomor 7 tentang Pengaturan Pasar Tradisional di Kabupaten Badung}

Terjadinya perkembangan investasi serta semakin banyaknya investor- investor asing yang berbisnis modern serta menanamkan modal bisnisnya di Indonesia untuk mendirikan pasar modern yang nantinya tentu berdampak pada pasar tradisional dan semakin bertambah banyak (Komariyah et al., 2020). Hal inilah menyebabkan keberadaan pasar tradisional mendapat ancaman besar, disebabkan oleh persaingan yang dilakukan pasar modern memiliki kemampun financial dan teknologi serta daya tarik modernisasi. perbedaannya fasilitas sangat menunjang seperti kebersihan dan juga kelengkapan produk yang dijual menyebabkan pasar tradisional menjadi tersaingi dan menjadi kurang diminati oleh masyarakat sebagai konsumen.

Kelemahan-kelemahan itulah lalu dijadikan ciri khas yang paling mendasar dari pasar tradisional yang tentunya sulit di ubah dalam doktrin masyarakatnya. Dimulai dari tampilan pasar, faktor desain, tata ruang, keragaman, waktu operasional pasar, kualitas barang, serta atmosfer, tata letak promosi pengeluaran, yang terbatas dan optimalisasi pemanfaatan ruang untuk suatu proses jual-beli merupakan hal yang menjadi kelemahan tersendiri dari pasar tradisional dalam hal menghadapi suatu daya saing bersama pasar-pasar modern yang menjadi daya tarik. Diantara berbagai kekurangan dan kelemahan pasar yang telah disebutkan, namun pasar-pasar tradisional pun tetaplah mempunyai beberapa potensi yang menjadi kekuatan dan keberhasilan, yang paling utama kekuatan sosial dibidang sosio emosional tentu pasar modern tak memilikinya.

Menurut Suartha, (2016) Kekuatan-kekuatan juga bisa di nilai dari beberapa unsur dan aspek seperti dekat dengan pemukiman, memberikan lebih banyak produk segar dan harga murah dan tentunya bisa ditawar. Keunggulan lainnya ialah pengalaman berbelanja. Produk-produk dapat langsung dipegang dan di coba yang umumnya tentunya lebih segar dan sangat segar jika dibandingkan. Perubahan dari gaya hidup didalam masyarakat menjadi seorang konsumen dalam perilakunya pada saat membeli barang diantaranya dipengaruhi oleh kemudahan-kemudahan yang 
diinginkan serta penjaminan mutu dari pasar modern yaitu skala ekonomi dan informasi harga. Adapun beberapa perbandingan yang dapat dilihat antara pasar modern dan pasar tradisional diantaranya ialah revitalisasi pasar tradisional, regulasi serta karakter atau budaya konsumen. Tetap erat kaitannya dengan pendirian dari pasar tradisional, pasar modern serta pusat perbelanjaan juga sudah ada yag mengatur pada aturan yang tertulis yakni pada Peraturan Presiden Nomor 112 Tahun 2007 tentang Penataan dan Pembinaan Pasar Tradisional, Pusat Perbelanjaan dan Toko Modern, yang dalam proses pembentukannya wajib hukumnya berpaku terhadap rencana penataan ruang wilayah kota atau kabupaten, hal-hal yang secara mendetail dari ruang kota atau kaupaten dan rencana disetiap provinsi yang disesuaikan dengan peraturan menurut zonasinya.

Dari ditentukannya penataan ruang wilayah yang olehnya diberikan lahan yang jelas untuk kegiatan usaha pada hakikatnya dikemudian hari tentu bergiliran untuk adanya suatu kemngkinan higher guna untuk membuat para investor tertarik serta akan menanamkan modalnya di daerah (Hamidi, 2011). Walaupun demikian, penataan ruang dari suatu wilayahpun tetap saja wajib perhatian dan melihat juga situasi serta kondisi ekonomi, budaya atau juga sosial dari kehidupan penduduk sekitar. Hal inilah yang menjadi pandangan penting gunanya agar penanaman investasi tersebut tidak smata-mata dapat menghasilkan suatu hal yang menguntukan bagi pemerintah daerah saja namun yang terpenting untuk kesejahteraan masyarakat di daerah.

Erat juga kaitannya dengan zona dari penataan ruangan yang tertera pada Pasal 4 Ayat (1) Peraturan Presiden yang telah diatur menyatakan pendirian dari pusat perbelanjaan serta toko modern diwajibkan memperhitungkan kondisi sosial ekonomi yang hidup di tengah-tengah masyarakat, Usaha Kecil, Usaha Menengah, keberadaan Pasar Tradisional, yang ada di daerah yang bersangkutan dan disediakannya fasilitas yang baik dan cukup memadai yakni yang hygienis, tertib, aman, bersih dan juga membuka ruang khalayak yang nyaman dan layak.

Permasalahan dari ditentukannya jarak di antara pasar tradisional dengan toko modern yang ada di Kabupaten Badung dengan contoh di wilayah Kuta Selatan setiap penerbitan ijin dari didirikannya tempat usaha seperti pasar baik itu pasar tradisional maupun pasar modern, pemerintah daerah tetap mengacu pada Peraturan Daerah Kabupaten Badung Nomor 7 tahun 2012 dengan berpedoman pada :

1. Undang-Undang Dasar Negara Republik Indoensia Tahun 1945,

2. Undang-Undang Nomor 12 Tahun 2008 tentang Perubahan Kedua Atas Undang-Undang Nomor 32 Tahun 2004 tentang Pemerintahan Daerah,

3. Undang-Undang Nomor 25 Tahun 2007 tentang Penanaman Modal,

4. Peraturan Menteri Perdagangan Nomor 53/MDAG/PER/12/2008 tentang Pedoman Penataan dan Pembinaan Pasar Tradisional, Pusat Perbelanjaan dan Toko Modern.

5. Undang-Undang Nomor 12 Tahun 2011 tentang Pembentukan Peraturan Perundang-undangan,

Berdasarkan wawancara dengan bapak Made Sutama pada tanggal 15 Oktober 2019 selaku Kepala Badan Pelayanan dan Perizinan Terpadu Kabupaten Badung mengatakan mengenai alasan perbedaan jarak pembangunan di tiga kawasan Kabupaten Badung tersebut dapat dibedakan berdasarkan tingkat kepadatan penduduknya dimana di kawasan Badung selatan tingkat kepadatan penduduknya sangat tinggi sehingga diperbolehkan dimungkinkan membangun pasar tradisional, pusat perbelanjaan dan toko modern dengan jarak 500 meter dengan pasar tradisional, pusat perbelanjaan dan toko modern lainnya, begitu pula dengan kawasan Badung lainnya mengikuti tingkat kepadatan penduduknya.

Hasil wawancara terhadap sala satu pengelola pasar tradisiaonal jimbaran (I Made Mertha) mengatakan bahwa pasar tradisional Jimbaran dapat digunakan dengan masyarakat untuk berdagang serta dapat menghasilkan pemasukan baik untuk pendapatan Desa Adat Jimbaran, Kelurahan Jimbaran ataupun pendapatan untuk masyarakatnya. Hal ini bisa kita flashback ke tahun 2010 sampai 2019 perkembangan pendapatan asli desa melalui pasar tradisional Jimbaran dibawah ini :

Tabel Perkembangan Pendapatan Asli Desa Jimbaran melalui pasar desa periode tahun 2013-2018.

\begin{tabular}{|c|c|c|}
\hline No & Tahun & Jumlah Pendapatan (Rp) \\
\hline 1 & 2014 & 13.600 .000 \\
\hline 2 & 2015 & 32.250 .000 \\
\hline 3 & 2016 & 41.430 .000 \\
\hline
\end{tabular}




\begin{tabular}{|l|l|l|}
\hline 4 & 2017 & 46.400 .000 \\
\hline 5 & 2018 & 58.000 .000 \\
\hline
\end{tabular}

Sumber: Data Hasil Olahan Penulis, 2016

Berdasarkan dari data tersebut diketahui bahwa perkembangan dari pendapatan asli yang ada di desa adat Jimbaran mulai dari tahun 2014 dan 2018 mengalami peningkatan yang sangat signifikan pada pendapatan asli desa dari pasar tradisional Jimbaran. Semestinya dengan diadakannya revitalisasi pasar tersebut pendapatan asli desa lebih tinggi dibandingkan dengan sebelumnya, namun tetapi pendapatan yang asli di Desa adat jimbaran dari tahun 2016 ke Tahun 2018 mengalami pendapatan asli desa yang relatif sedikit dan menurun, hal ini merupakan salah satu faktor dari terhambatnya revitalisasi pasar itu sendiri.

\section{Hambatan Implementasi Revitalisasi Perda Kabupaten Badung Nomor 7 tentang Pasar Tradisional di Kabupaten Badung}

Adanya pasar tradisional ini adalah bagian dari system daei aspek ekonomi kerakyatan yang dimana artinya suatu sistem yang basisnya kekuatan dari rakyat itu sendiri (Runtuh, 2011). Ekonomi dari rakyat kelas bawah ini yang menjadi tumpuan hidup beberapa bagian besar rakyat Indonesia yang ada diwilayah pedesaan. Berdasarkan dari pengertian ekonomi kerakyatan yang artinya sebuah sistem ekonomi yang berpihak kepada rakyat menengah ke bawah, maka dari hal tersebutlah maka sudah menjadi sebuah kewajiban bagi pemerintah bisa untuk memberdayakan serta melindungi dari pada masyarakat daerah, terutama untuk masyarakat yang bergerak pada sektor ekonomi kecil atau mikro seperti contohnya yakni pedagang-pedagang di pasar tradisional yang ada pada setiap daerah.

Tak dapat dipungkiri apabila laju peningkatan Pendapatan Domestik Regional Bruto yang disingkat (PDRB) dan Pendapatan Anggaran Daerah (PAD) di daerah khususnya di Kabupaten Badung tentu saja juga dipegang oleh perkembangan dari keberadaan pasar tradisional yang ada di daerahnya tersebut. Berdasarkan dari alasan-alasan tersebut di atas, maka disebabkan oleh konstribusi dari pasar tradisional itu layak untuk dipertahankan bahkan eksistensinyapun juga wajib diperkuat. Jika diperhatikan lebih jauh, terdapat pula banyak keunggulan atau spesifikasi dari pasar tradisional itu sehingga pantas untuk dipertahankan keberadaannya di masyarakat. Ini yang lalu memberi perbedaan mengenai keberadaan pasar tradisional dengan pasar modern dan menjadi suatu keunggulan yang dimiliki oleh pasar tradisional dan untuk itu layak dijaga pada masa yang akan datang. Spesifikasi pasar tradisional jika disambungkan dan didekatkan dengan analisis SWOT (Strength, Weakness, Opportunity, dan Threat) meliputi;

1. Pada sudut pandang kelengkapan pada penyediaan barang yang akan dijual

2. Masyarakat yang memiliki modal kecil dapat tertampung di dalam perdagangan pasar tradisional

3. Macam-macam kalangan tingkat pendidikan dapat masuk ke pasar tradisional untuk berdagang

4. Untuk sejumlah produk

Wakil ketua komisi pengawas persaingan usaha (KPPU) memiliki penilaian pada peraturan menteri dalam negeri atau Permendag Nomor 53 Tahun 2008 itu mandul dalam hal pelaksanaannya dalam kehidupan bermasyarakat dimana menurut beliau, aturan tertulis yang menangani bidang regulasi pasar modern dan juga tradisional ini sudah ada sebelumya. Tetapi dalam hal pengimplementasikan masih tidak jelas pelaksanaanya, sehingga bisa saja menjadi amncaman untuk keberadaan dari pasar tradisional itu sendiri. Akibat dari hal tersebut, maka banyak dari pasar-pasar tradisional yang sudan merasakan penurunan pendapatan atau omzet lumayan besar. Salah satu kelemahan dari pasar tradisional sepanjang masa ini minim dalam perhatian dari warga sekitar ialah karena kumuhnya pasar itu sendiri yang nantinya mengurangi minat konsumen untuk datang ke pasar untuk sekedar berbelanja. Namun bisa dimaklumi pula bahwa hingga saat ini pun pasar tradisional masih tidak lepas dari kesan tidak rapih, bau, becek, sarana serta prasarananya juga terbatas yang nantinya menjadikan sulitnya pasar tradisonal untuk bersaing dengan pasar modern yang ada saat ini. Kompleksitas pembatalan terhadap produk hukum daerah yang berbentuk Peraturan Daerah (Perda) dan Peraturan Kepala Daerah maupun bentuk yang lainnya merupakan keniscayaan dalam mewujudkan peran dan fungsi hukum dalam menopang proses pembangunan menuju masyarakat yang adil dan sejahtera (Hamidi, 2011). Pengaturan dari jarak pembangunan pasar tradisional dan pasar modern, serta pusat perbelanjaan di Kabupaten Badung ini telah diatur secara tertulis pada Pasal 
7 Peraturan Bupati Badung Nomor 10 Tahun 2014 tentang Petunjuk Pelaksanaan Peraturan Daerah Kabupaten Badung Nomor 7 Tahun 2012 tentang Penataan dan Pembinaan Pasar Tradisional, Pusat Perbelanjaan dan Toko Modern. Dimana dalam pasal 7 tertera bahwa persyaratan dari penentuan jarak pendirian pasar tradisional, pusat perbelanjaan dan toko modern haruslah memberikan pertimbangan dari lokasi di bentuk ataupun dibangunnya pusat perbelanjaan, pasar tradisional ataupun juga toko-toko modern dengan tempat pasar modern dan pasar tradisional yang telah didirikan dan beroperasi dari waktu-waktu sebelumnya, mempertimbangkan pula iklim usaha yang sehat tanpa adanya kecurangan, ketersediaan infrastruktur, aksesibilitas wilayah atau arus lalu lintas dan juga perkembangan pemukiman baru.

Ada pula beberapa hambatan pada saat implementasi revitalisasi pembangunan pasar tradisional Jimbaran diambil dari hasil penelitian yang ada di lapangan adalah sebagai berikut:

\section{Faktor Keuangan}

Tanpa adanya dana yang cukup segala rencana yang akan di implementasikanakan menjadi tidak terealisasi. Faktor dana inilah yang merupakan faktor yang paling vital di dalam implementasi revitalisasi pasar tradisional yang terdapat diberbagai daerah, karena dalam pengimplementasiannya pasar tradisional memerlukan kegiatan berupa perbaikanan, penyuluhan, gedung, sosialisasi dengan oral maupun dengan media dan pembinaan serta kegiatan-kegiatan lainnya yang tentu akan memerlukan biaya atau dana untuk mensukseskan aktivitas tersebut secara maksimal dan totalitas.

2. Fator penegakan hukum

Penegakan hukum ialah factor yang sangat berpengaruh karena banyaknya orang seringkali menimbulkan kesalahpahaman, maka dari itu wajib adanya penegakan hukum untuk menertibkan pasar dan memberi sanksi tetap kepada aturan yang telah dilanggar dengan tujuan keadilan dan kesejahteraan masyarakat.

3. Faktor

Pembeli maupun penjual yang tidak mengerti tentang disiplin keamanan, kebersihan dan kenyaman seringkali melakukan perbuatan yang seenaknya sendiri seperti buang sampah hasil penjualan, yang mana perbuatan tersebut secara langsung ataupun tak langsung memiliki dampak yang berpengaruh pada terhambatnya revitalisasi pasar tradisional yang mengutamakan kenyamanan serta kebersihan. Di pasar tradisional

4. Faktor pengelola

Setiap pengelola wajib memiliki cara pandangg yang baik atas kinerja serta memiliki prospek yang baik kedepannya bagi kelanjutan dari pasar tradisional. Karena apabila pengelola telah mencapai target-target yang di upayakan pencapaiannya demi kemajuan pasar tradisional, maka setidaknyapun akan terdapat pula upaya-upaya untuk peningkatan peran dan juga daya untuk bersaing antara pasar tradisional dari pasar modern yang telah didirikan. Dari tager tersebutlah setidaknya akan terdapat perubahan dari mengimplementasikan revitalisasi pasar tradisional secara bertahap.

\section{SIMPULAN DAN SARAN}

\section{Simpulan}

Berdasarkan anailsis data, hasil penelitian ini menunjukkan bahwa Implementasi revitalisasi pembangunan pasar tradisional di Daerah badung ialah salah satu gebrakan dari pemerintah yang bertugas di daerah dalam hal menghidupkan serta mengembangkan kembali pasar yang sebelumnya mengalami penurunan yang disebabkan dari persaingan dengan pasar modern yang tumbuh, untuk itu dengan diundangkannya peraturan daerah Nomor 7 Tahun 2012 tentang penataan dan pembinaan pasar tradisional, pusat perbelanjaan dan toko modern menjadikan eksistensi pasar tradisional menjadi lebih baik dan perkembangan, yang kedua Hambatan-hambatan implementasi revitalisasi pasar tradisional bersadar peraturan daerah nomor 7 Tahun 2012 tentang penataan dan pembinaan pasar tradisional, pusat perbelanjaan dan toko modern terletak pada faktor penegakan aturan, faktor dana, faktor pengelolaan dan faktor masyarakat.

\section{Saran}

Adapun yang disarankan oleh peneliti adalah diharapkan kepada masyarakat terkait implementasi revitalisasi dan pembangunan pasar tradisional Jimbaran diharapkan dapat meninjau kembali agar pembangunannya untuk tetap berkelanjutan demi revitalisasi pasar tradisioanl untuk kemajuan dan penguatan daya saing pasar tradisional dengan pasar modern, karena pasar tradisional Jimbaran ialah 
bagian terpenting sebagai penunjang pendapatan desa adat Jimbaran, selanjutnay diharapkan kepada pemerintah desa adat dan pemerintah daerah wajib selalu berkoordinasi untuk mencari jalan keluar terbaik untuk menggulangi hambatan-hambatan implementasi revitalisasi pasar tradisional untuk pengembangan, kemaujuan serta daya saing pasar tradsional dengan pasar modern yang semakin menjamur di wilayah pedesaan.

\section{DAFTAR PUSTAKA}

Fajrul Umami, Z. H. (2018). Implementasi Peraturan Daerah Kota Semarang Nomor 9 Tahun 2013 tentang Pengaturan Pasar Tradisional. 7(4), 1-15.

Hamidi, J. (2011). Paradigma Baru Pembentukan Dan Analisis Peraturan Daerah (Studi Atas Perda Pelayanan Publik Dan Perda Keterbukaan Informasi Publik). Jurnal Hukum Ius Quia Iustum, 18(3), 336-362.

Komariyah, S., Putriya, H., \& Sutantio, R. A. (2020). Dampak Investasi Kinerja Ekspor dan Inflasi dalam Penyerapan Tenaga Kerja Indonesia: Analisis Data Panel. Jurnal Ekonomi Dan Keuangan, 3(4), 464483.

Kuriaty, H. (2017). Pengaruh Jumlah Pembeli Terhadap Keuntungan pada Toko Kelontong Sebelum dan Sesudah Berdirinya Mini Market di Kota Buntok Kalimantan Tengah. Anterior Jurnal, 17(1), 28-32.

Luh, N., Wulandari, Y., Yudharta, I. P. D., Yasintha, P. N., \& Kuta, K. (2018). Implementasi Peraturan Daerah Kabupaten Badung Nomorv7 Tahunv2012 tentang Penataanvdan Pembinaan Pasar Tradisional Pusat Perbelanjaan dan Toko Modern. FJurnal Akultas Ilmu Sosial Dan Ilmu Politik Universitas Udayana, 2(2).

Runtuh, M. (2011). Pasar dan Ekonomi Kerakyatan Indonesia. Media Pustaka.

Sarwoko, E. (2008). Dampak Keberadaan Pasar Modern Terhadap Kinerja Pedagang Pasar Tradisional Di Wilayah Malang. Jurnal Ekonomi Modernisasi, 4(2), 97-114.

Suantra, I. N., Nurmawati, M., \& Asih, D. S. (2018). Engaturan Perizinan Toko Swalayan sebagai Potensi Pendukung Kepariwisataan di Bali. Urnal Vyavahara Duta, 13(2).

Suartha.N. (2018). Industri Pariwisata Bali. Raja Grpindo.

Suartha, N. (2016). Selamatkan Pasar Tradisional Bali Berbasis Pelanggan. Raja Grafindo Press. 